\title{
Ceremonial Demarcations. The Viceregal Court as Space of Political Communication in the Spanish Monarchy (Valencia, Naples, and Mexico 1621-1635)
}

\author{
Christian Büschges
}

In political and political-historical pamphlets of the Enlightenment and the nineteenth century as well as in traditional political history, ceremony has been seen as an embellishing, vain, and superfluous accessory of the 'real', rational, political acts that were regulated by legal norms and institutions. Modern historiography, on the other hand, taking into account sociological and ethnological approaches, emphasises the specific rationality and political nature of ceremony, which is, in turn, only a form of expressing the symbolic dimension inherent in every political communication and interaction. ${ }^{1}$

At the early-modern court the function of ceremony, which stood out from the spontaneous, individual, everyday acts, lay in making visible the system of monarchical rule and the social and political ranks inherent in it. Ceremony granted the courtiers a visible position in the oft-disputed curial ranking and at the same time fitted external visitors into this symbolic representation of hierarchy. $^{2}$

Using the example of the court of Louis XIV of France, Norbert Elias, in his study on the 'court society' (Die höfische Gesellschaft), which sparked the revival of modern court research, considered ceremony as an exclusive instrument of power of monarchical absolutism. ${ }^{3}$ While Elias coined the image of the court as a 'golden cage' used by the absolutist ruler to domesticate the nobility, he also pointed out the 'very specific network of interdependencies' that connected the king as primus inter pares to the noble court society and

1 Barbara Stollberg-Rilinger, 'Zeremoniell als politisches Verfahren. Rangordnung und Rangstreit als Strukturmerkmale des frühneuzeitlichen Reichstags', in Johannes Kunisch, ed., Neue Studien zur frühneuzeitlichen Reichsgeschichte (Berlin, 1997), 91-4; cf. Maria Antonietta Visceglia, 'Il ceremoniale come linguaggio politico. Su alcuni conflitti di precedenza alla corte di Roma tra Cinquecento e seicento', in Maria Antonietta Visceglia and Catherine Brice, eds., Cérémonial et rituel à Rome (XVIe-XIXe siècle) (Rome, 1997), 117-176.

2 Stollberg-Rilinger, 'Zeremoniell als politisches Verfahren', 95; cf. Volker Bauer, Hofökonomie. Der Diskurs über den Fürstenhof in Zeremonialwissenschaft, Hausväterliteratur und Kameralismus (Vienna, 1997), 34f.

3 Norbert Elias, Die höfische Gesellschaft. Untersuchungen zur Soziologie des Königtums und der höfischen Aristokratie (2nd ed., Frankfurt/M., 1994). 
thus included him in the representation and competition of social and political ranks that were concentrated at the court. ${ }^{4}$

In more recent time, several scholars have made clear that ceremony, absolutism, and domestication of the nobility were not firmly joined together in the framework of practice of early-modern rule and that there were clear differences between royal courts. A highly distinguished court ceremonial, on the one hand, could point towards a not fully realised and recognised kingship, while, on the other hand, it could be an expression of and compensation for the progressive loss of power of an established ruler. ${ }^{5}$

For this reason, court ceremony should be looked at from the perspective not only of the ruler but also from that of other participants, especially the court nobility. Ceremonies gave all persons taking part a chance to represent, defend, or improve their social and political rank at court and beyond. ${ }^{6}$

The complex character of the social and political representation and interaction at court becomes clear when we look at the royal court of the Spanish Habsburgs in Madrid, where in the course of the sixteenth and seventeenth centuries court and ceremony underwent several changes. Since 1584 the Spanish holding of court had followed the Burgundian court ceremonial introduced by Charles V. ${ }^{7}$ Under his son Philip, the Spanish court assumed a less public, distanced, and rather bare, religious character and was distinguished by the extreme formality of its ceremony. ${ }^{8}$ Under Philip III, however, a splendid life at court developed under the direction of the king's favourite duke of

4 Elias, Die höfische Gesellschaft, 12, 312-14; cf. Aloys Winterling, “"Hof”. Versuch einer idealtypischen Bestimmung anhand der mittelalterlichen und frühneuzeitlichen Geschichte', in Aloys Winterling, ed., Zwischen 'Haus' und 'Staat'. Antike Höfe im Vergleich (Munich, 1997), 24. With regard to Elias' concept of the court in general Jeroen Duindam, Myths of power. Norbert Elias and the early modern European court (Amsterdam, 1995).

5 See e.g. Aloys Winterling, Der Hof des Kurfürsten von Köln 1688-1794. Eine Fallstudie zur Bedeutung 'absolutistischer' Hofhaltung (Bonn, 1986), 151-170; Olaf Mörke, 'Stadtholder' oder 'Staetholder'? Die Funktion des Hauses Oranien und seines Hofes in der politischen Kultur der Vereinigten Niederlande im 17. Jahrhundert (Münster, 1997), 21-28; Werner Paravicini, ed., Zeremoniell und Raum (Sigmaringen, 1997).

6 See e.g. the case of Vienna in Andreas Pecar, Die Ökonomie der Ehre. Der höfische Adel am Kaiserhof Karls VI. (1711-1740) (Darmstadt, 2003).

7 Ludwig Pfandl, 'Philipp II. und die Einführung des burgundischen Hofzeremoniells in Spanien', Historisches Jahrbuch 58 (1938), 1-33.

8 John H. Elliott, 'The court of the Spanish Habsburgs: a peculiar institution?', in John H. Elliott, Spain and its world 1500-1700. Selected essays (New Haven and London, 1989), 142-161; Christina Hofmann, Das spanische Hofzeremoniell 1500-1700 (Frankfurt/M., 1985); Regine Jorzick, Herrschaftssymbolik und Staat. Die Vermittlung königlicher Herrschaft im Spanien der frühen Neuzeit (1556-1598) (Munich, 1997), 152-188. 
Lerma, a life in which the king, however, was pushed from his position as head and centre of the court to the margins by the noble court society, who used the court to display their own positions and power. ${ }^{9}$ Under Philip IV, it was again a favourite, the count-duke of Olivares, who extended the court and its ceremony as a propagandistic instrument of monarchical sovereignty..$^{10}$ Olivares tried to turn the court into the model and centre of the aristocratic culture of Spain before, under the weak and frail Charles II $\left(1665^{-1700}\right)$, the factions of the Spanish nobility could strengthen their position at court again.

The examples mentioned above show how court ceremony responded to changing patterns of rulership, in particular to the political relationship between the prince and the other political actors around the court. In this article I broaden this discussion to the cases of the viceregal courts of the Spanish monarchy, concentrating on the realms of Valencia, Naples, and New Spain (Mexico). Research concerning the 'composite monarchy' (J.H. Elliott) of the Spanish Habsburgs and the political relationship between the royal court at Madrid and the different territories of the monarchy in Europe and America has elucidated the role of the viceroy within the complicated arrangement of institutional and personal relations that characterised the government of the vast transatlantic empire during the sixteenth and seventeenth centuries. However, only in recent years has the viceregal court been analysed as a topographical and political space in its own right, where political ranks and interests were communicated and negotiated. ${ }^{11}$ This is especially true with regard to the ceremonial rules and practices that both reflected and shaped the political relationship between the viceroy and other social and political actors with access to the viceregal court.

I begin by describing the role of the Spanish viceroy and the viceregal court within the royal government in the three realms under consideration. Secondly, I will address the extent and function of ceremonial rules within the three viceregal courts. Thirdly, I will discuss ceremonial disputes as a part of the political communication at these courts. This comparative approach highlights differences and similarities in political communication at these different viceregal courts. While these variations were related to the social and

9 Antonio Feros, Kingship and favoritism in the Spain of Philip III, 1598-1621 (Cambridge, 2000).

10 John H. Elliott, 'Staying in Power. The Count-Duke of Olivares', in John H. Elliott and L.W.B. Brockliss, eds., The World of the Favourite (New Haven and London, 1999), 112-122.

11 Francesca Cantú, ed., Las cortes virreinales de la Monarquía española: América e Italia (Rome, 2008); Pedro Cardim and Joan Lluis Palos, eds., El mundo de los virreyes en las monarquías de España y Portugal (Frankfurt/M and Madrid, 2012). 
political importance of the three realms within the Spanish monarchy, they also depended on the local social contexts and traditions. Finally, this paper underlines the relevance of the individual skills of the viceroys in dealing with competing interests at court and in the viceregal capital.

\section{The Viceroy and the Viceregal Court of the Spanish Monarchy}

As the representative of the king, the viceroy exercised political power delegated by the monarch, while he was legitimised as well as limited by law and tradition. ${ }^{12}$ In his everyday business at his seat of power he had to deal with different individuals, groups, and institutions all with their own specific and partially competing social and political interests. At the same time, the viceroys were-as were the other royal as well as clerical office-holders and institutions in the respective kingdoms - under the control of the king and his councillors in Madrid.

Thus the viceroy was not a sovereign but a subject in the service of the king. On the one hand, he represented the monarch in the viceregal territory of jurisdiction, and, on the other, he exercised temporally, spatially, and substantially limited power delegated by the monarch. In the kingdom handed over to him, the viceroy was the head of the royal government and legal administration, captain-general, and vice-patron of the dioceses belonging to the royal church patronage. The viceroy was also in charge of part of the royal patronage. To a degree that varied according to which kingdom he headed, the viceroy himself was able to appoint officers, fill vacant positions temporarily, or make suggestions to the king as to whom he should appoint to office. He also made recommendations and gave advice to the king and the responsible royal councils in Madrid regarding the awarding of noble titles and other favours.

From the late sixteenth century the viceroys came, as a rule, from the Castilian high nobility. The position of the viceroy was one of the most important posts during the career of these noblemen, which started at the king's court and led, in the ideal case, through a range of military and political positions at court and outside of it to a seat in the council of state.

12 On the viceregal government see José Montero Alonso, Los virreyes españoles en América (Barcelona, 1991), Lillian E. Fisher, Viceregal Administration in the Spanish-American Colonies (Berkeley, 1926); Christian Büschges, 'La corte virreinal como espacio político. El gobierno de los virreyes de la América Hispánica entre monarquía, élites locales y casa nobiliaria', in Pedro Cardim and Joan Lluis Palos, eds., El mundo de los virreyes en las monarquías de España y Portugal (Frankfurt/M and Madrid, 2012), 319-343. 
Whereas the viceroys had enjoyed especially extensive powers and a high degree of responsibility until the middle of the sixteenth century, Philip II limited their power in favour of various specialised administrative institutions and expert officials (letrados). From the late sixteenth century the tasks of the viceroy centred on counselling the king and implementing his royal policies at the local level. In spite of this concentration of political power in Madrid, the court of the viceroy, because of the political necessity of tying the local authorities to the monarchy, remained an important centre of political representation and interaction.

Following the model of the king's court, the viceroy as alter ego of the monarch and highest political authority in matters of government and administration was supported by a council (e.g. the Consejo in Valencia, the Consiglio Collaterale in Naples, or the Real Acuerdo in Mexico) and by committees (juntas) created to deal with specific matters. The councils, which were made up of royal officials of the highest ranks coming from the capital of the kingdom, not only served the viceroy by giving advice, but they also controlled his activities in office. All members of the council were, however, bound to execute the viceregal orders even if they violated law or tradition. In such cases, the councillors had to inform the king, who alone had the right to take action against the viceroy if he considered it necessary.

Apart from the royal officials subordinate to him, the most important individuals and institutions that the viceroy had to deal with in governing his kingdom included city councillors, institutions of the church, and the inquisition. The king's absenteeism and the viceroy's lack of sovereignty led to frequent disputes between the different secular and clerical institutions about administrative and especially legal competences, often involving the viceroy. ${ }^{13}$ The arbitration proceedings available for reaching a peaceful agreement on jurisdictional matters had only limited success since the regulations were often ambiguous and only the monarch had the right to make a final decision-a process which could take several weeks or months or even, as sometimes in the case of Spanish America, over a year. The king, therefore, urged his viceroys to seek consensus with secular and clerical authorities and to settle conflicts developing among them.

As the symbolic expression of their double function as highest royal official and alter ego of the monarch, the viceroys of the Spanish monarchy lived in a

13 Cf. for the case of Mexico, Christian Büschges, ‘¿Absolutismo virreinal? La administración del marqués de Gelves revisada (Nueva España, 1621-1624)', in Anne Dubet and José Javier Ruiz, eds., Las monarquías española y francesa (siglos XVI-XVIII) ¿Dos modelos políticos? (Madrid, 2011), 31-44. 
representative building called the royal palace (Casa Real in Valencia, Palazzo Reale in Naples, and Palacio Real in Mexico). All three royal palaces accommodated, besides the viceroy and his household, a viceregal guard and various palace officials. In addition to the rooms used by the viceroys for public audiences and festivities, other parts of the palaces were reserved for meetings of various administrative institutions. The royal officials did not live in the palace since it was reserved for the representative of the monarch, his personal entourage, and servants. The high officials of the king did come under the viceroy's political authority and can be seen, therefore, as belonging to the viceregal court, but they were appointed by the king and thus had a certain degree of independence, which sometimes became visible in disputes over jurisdiction.

The private rooms of the viceroys were always on the first story of the palaces while the viceregal guards and most of the servants were accommodated on the ground floor. As far as can be seen from the sources, a staircase led to the upper story and access to the private rooms of the viceroys was achieved by passing through a sequence of rooms as was the practice in most European courts. The structure of the palaces and the usage of the rooms were partially adapted by the different viceroys to fit their individual needs and likings.

The royal palace of Valencia, built in Aragonian time, was situated outside the city walls and was reached from the town through the Portal del Real and over the Pont del Real, which spanned the river Uria. The palace was surrounded by elaborate, artfully designed gardens. ${ }^{14}$ The viceroys of Naples had lived until the middle of the sixteenth century in the Castel Nuovo, a medieval castle built by Charles I of Anjou, which lay right outside the city walls near the port. The viceroy Pedro de Toledo, duke of Alba (1532-1553), had a new royal palace built inside the city walls, finished in 1565 , near the Castel Nuovo. At the beginning of the seventeenth century construction was begun on a new, bigger royal palace. This new building, sited next to the Pedro de Toledo's palace, suited the requirements of early-modern life at court much better. Its basic structure was finished in 1616 , and its façade was completed in $1631 .{ }^{15}$

The building of the royal palace, situated in the centre of Mexico City, had originally belonged to the Aztec ruler Moctezuma before the conquistador Hernán Cortés received it as a present from Emperor Charles V and altered it to accommodate his needs. Cortés' descendants gave it back to the Crown, and, with Luis de Velasco (1590-1595), the first viceroy moved into the building. He then altered it further to suit the needs of his household and of the

\footnotetext{
14 Cartografía Valenciana (siglos XVI-XIX) (Valencia, 1997); Pilar de Insausti, Los jardines del Real de Valencia. Origen y plenitud (Valencia, 1993).

15 Cesare de Seta, Napoli fra Rinascimento e Illuminismo (Naples, 1997).
} 
governmental institutions that were accommodated in the palace. The palace and adjacent garden were situated on the east of the Plaza Mayor, the main market place of the town, on whose northern side stood the cathedral. ${ }^{16}$

The viceregal courts did not form spaces that were strictly separated from the town and its social life. ${ }^{17}$ This holds true even for the viceregal palace of Valencia, which was situated outside the city walls on the west bank of the river Uria, but which could be reached easily by the inhabitants of the town. On the side of the palace the banks of the river formed a public, tree-lined boulevard stretching from the Pont del Real, which linked the forecourt of the palace with the town, to the Pont del Mar situated further north. This boulevard, the Alameda, was very popular not only with the urban nobility but also with the common people especially on weekends. ${ }^{18}$ The viceroys, in turn, accompanied by their entourage took part in the social life of their capital cities at various events.

By the sixteenth century, especially in Valencia and Naples, the royal palaces had developed into centres of aristocratic sociability, which had a decisive influence on urban culture in the capitals of the kingdoms. Since the first half of the sixteenth century many families of the traditional feudal nobility of these two kingdoms had settled in the capital, where they formed, together with the old-established patricians, an extensive courtly-aristocratic environment. In Mexico, on the other hand, there had not been such a development until the beginning of the seventeenth century. In the sixteenth century the Crown had prevented the development of feudal nobility in New Spain and all of Spanish America. Thus, only in the course of the seventeenth century and especially in the eighteenth century, did a local nobility develop, furthered by an increasing awarding of noble titles and memberships in clerical orders of knights that were clearly recognisable by outer attributes and concentrated in

16 Artemio Valle-Arizpe, 'Doctor Isidro Sariñana', in Artemio Valle-Arizpe, Historia de la ciudad de México según los relatos de sus cronistas (Mexico, 1977), 349-363.

17 This is not a particular attribute of the Mexican court, as Pietschmann argues, Horst Pietschmann, 'La corte de México en el siglo XVII en sus dimensiones jurídicoinstitucionales, sociales y culturales: aproximación al estado de la investigación', in Monika Bosse, Barbara Potthast and André Stoll, eds, La creatividad feminina en el mundo barróco hispánico. María de Zayas-Isabel Rebeca Correa-Sor Juana Inés de la Cruz (Kassel, 1999), vol. 2, 481-497.

18 Manuel Sanchis Guarner, 'Aspecte urbà de València al segle XVI', in La Corona de Aragón en el siglo XVI (Valencia, 1973), vol. 3:1, 100-102. 
the capital of the kingdom..$^{19}$ The role of the viceregal court in the spreading and deepening of aristocratic culture within the Mexican upper class has yet to be investigated. ${ }^{20}$

In Valencia the viceroy and duke of Calabria Ferdinand of Aragon $(1526-$ 1550) had played a pioneering role in the development of a stately court and urban culture. ${ }^{21}$ The duke with his nobles, artists, writers, and musicians present at the court established an extensive, aristocratic cultural life, which after his death was continued also outside the court by various urban noble academies. ${ }^{22}$ The courtly and patrician culture of Valencia experienced a further aristocratisation when it became the site of the 1599 wedding of King Philip III, organised by his favourite and viceroy at the time, the duke of Lerma. ${ }^{23}$

The high social standing of the Valencian and, particularly, the Neapolitan viceroys, in part, accounted for the aristocratic sociability and ceremonial nature of those courts. The court of Naples was a particularly attractive post for titled nobles and even grandees, which was not the case with the courts of Spanish America. Furthermore, distinguished social and political personalities of the Spanish monarchy were often guests in the royal palaces of Valencia and Naples but not in faraway Mexico. In the royal palaces of Valencia and Naples festivals and balls in which numerous members of the local nobility participated were frequent events.

\section{Court Life and Ceremony}

Life at court, including the viceroy's formal public appearances in the capital, was characterised by various ceremonial acts, standardised by law and tradition, in which the viceroy as the representative of the monarch was the centre of attention. Among these, the everyday events in the viceregal residence can

19 Cf. Christian Büschges, 'Don Quijote in Amerika. Der iberoamerikanische Adel von der Eroberung bis zur Unabhängigkeit', in Friedrich Edelmayer, Bernd Hausberger and Barbara Potthast, eds., Lateinamerika, 1492-1850/70 (Vienna, 2005), 154-170.

Cf. Xavier Gil Pujol, 'Una cultura cortesana provincial. Patria, comunicación y lenguaje en la Monarquía Hispánica de las Austrias', in Pablo Fernández Albaladejo, ed., Monarquía, imperio y pueblos en la Espana moderna (Alicante, 1997), vol. 1, 225-257.

21 Francesc Almela y Vives, El Duc de Calabria y la seua Cort (Valencia, 1958); Juan Oleza Simó, 'La Valencia virreinal del Quinientos: una cultura señorial', in M.V. Diago Momgholi, ed., Teatro y práctias escénicas, vol. 1., Quinientos valenciano (Valencia, 1984), 61-75.

22 Oleza Simó, 'La Valencia virreinal del Quinientos', 64-67.

23 Oleza Simó, 'La Valencia virreinal del Quinientos', 69-70. 
be distinguished from the special political ceremonies within the palace and at other places in the capital.

Within the complex framework of the Spanish monarchy, these ceremonies symbolically represented the splendour of the king's dynasty, the unity of monarchy and kingdom, and the social and political rank of the individuals, groups, and institutions participating. Ceremony at the viceregal courts was not based on written regulations (at least until the middle of the seventeenth century), nor was the ceremonial of the Spanish royal court officially used as a standard and model for the viceregal courts. The king, however, issued concrete laws and orders concerning particular ceremonial questions at the viceregal court. Clearly, not only the political functioning, but also the viceroy's style of court life was formally under the control of the monarch. A maestro di cerimonia and an usciere maggiore, appointed by the king, kept an eye on compliance with Neapolitan court ceremonial during all public acts the viceroy conducted or attended in the palace or in town. ${ }^{24}$ In Naples as well as in Valencia elements of the holding of court from Aragonian times were possibly passed down to the time of the Spanish Habsburgs. This aspect still awaits investigation, as does the possible input of indigenous traditions into the symbols of power of the viceregal courts in Spanish America.

As at other European courts, not all aspects of the ceremony at the viceroys' court were political in nature or aimed at the illustration of the structure of monarchical rule and its social and political ranks. Ceremonies also permeated everyday life at court. At the same time, however, certain everyday ceremonial acts could have a political meaning. This holds especially true for the official viceregal audiences, during which the inhabitants of the kingdom could bring forward their concerns or requests to the viceroy in person.

In the case of Naples and Mexico some contemporary writings give an idea of the political meaning of ceremony at the viceregal court and of the viceroy's public appearances in the capital. The 'Reglas y Advertencias' addressed to the duke of Alcalá in 1628, whose authorship has not been recorded, urge the designated viceroy of Naples to go to Mass held in the royal palace on a regular basis. When he attends Mass, he is escorted from his rooms to the chapel by high-ranking royal officials and judges, the majority of the urban nobility, military captains, and viceregal favourites, 'with the result that his appreciation and the respect shown to him' are increased. ${ }^{25}$

\footnotetext{
24 Giulio Cesare Capaccio, Il Forastiero (Naples, 1634), 410-1.

25 'Reglas y advertencias al duke of Alcalá para el gobierno de Nápoles' (Madrid, 8.10.1628), Biblioteca Nacional, Madrid (BN/Ma), Manuscritos, no. 6938/5, 123-198.
} 
Furthermore, the 'Reglas y Advertencias' emphasised, as did the Neapolitan author Giulio Cesare Capaccio in his 1634 work Il Forastiero dedicated to the viceroy count of Monterrey, the special meaning of the viceregal audiences, where the viceroy represented the king in a very direct way and should, therefore, according to the 'Reglas y Advertencias', respond to the petitioners with few, dignified words. ${ }^{26}$ In this way the audience and its ceremonial organisation could serve the viceroy as an opportunity to demonstrate his high political standing through symbolic acts and words, which served the purpose of distancing himself from others.

For New Spain, an unofficial instruction provides an insight into court life. This instruction was given to the designated viceroy marquis of Montesclaros before he left for Mexico in 1603 by Pablo Laguna, president of the council of Indies. ${ }^{27}$ The preserved parts of the text deal with the person and the office of the viceroy and with the viceregal household, referring in some points to the practice of former viceroys. The rules of behaviour suggested to the NewSpanish viceroy also aim at maintaining a certain appearance in front of royal officials and favourites and the public of the capital. This appearance was modelled after the image of the monarch and was designed to command respect by keeping a dignified distance. Additional suggestions regarding the viceroy's political rank are given for ceremonial dining in the palace, indicating the social and political ranks of the participants.

From available sources we have only a single case to indicate to what extent these rules and suggestions for viceregal behaviour were actually followed. One must not forget, however, that the character and the personal preferences of the several viceroys played an important role in determining behaviour. Whereas the public appearance of the New-Spanish marquis of Gelves (1621-1624) was unanimously judged by his contemporaries as conscientious, distanced, and strict, critics accused his successor, the marquis of Cerralvo (1625-1635), of a demeanour unworthy of his office. A royal official questioned during a customary judicial investigation (juicio de residencia) following his time in office accused the marquis, among other things, of having been present at the meetings of the Real Acuerdo with rolled-up sleeves. ${ }^{28}$ Compared to

26 'Reglas y advertencias', 128-129, 140.

27 'Advertencias de las cosas en que ha de tener particular cuidado el virrey de la Nueva España' (Madrid, 14.1.1603), в /Ma, Manuscritos, no. 3207, 679-688.

28 Testimony of Don Francisco de Samaniego, 'Información de testigos seguida en la pesquisa secreta de la residencia que Don Pedro de Quiroga y Moya tomó al marquis of Cerralbo, sus criados y allegados' (Mexico, 28.9.1635), Archivo General de Indias, Seville (AGI), Audiencia de México, legajo 32, 678v-941v. 
this charge, the accusation of having abused symbols of power and rank was far more serious. Among other things, the marquis was said to have introduced golden and black keys for his personal servants and a mace for his mayordomo mayor in the royal palace. In addition, he used several six-in-hand coaches brought in from Spain, which were lavishly designed and had glass windows and golden handles, although this type of vehicle was reserved for the monarch and his diplomats. The public appearance of the marquis of Cerralvo, apparently complemented by excessive festivals and balls, deviated conspicuously from the suggestions that the president of the council of the Indies had given to one of Cerralvo's predecessors before his departure to Mexico and in which the four-in-hand coach meant for viceroys is mentioned. The case of the marquis of Cerralvo also makes clear that viceregal court life and ceremony served not only to represent the monarch but also provided the viceroys an instrument for demonstrating - and enlarging - the political and social standing of themselves and their families. ${ }^{29}$

In addition to the ceremonies at the viceregal court described above, the viceroy as alter ego of the king was also the centre of attention during various public occasions in his respective kingdom. During such ceremonies, the political system of the Spanish monarchy was staged on the streets and market places and in the churches of the town.

Philip IV's visit to Valencia in 1632 remained the king's only journey before 1635 to one of the kingdoms investigated here. In 1629, however, Philip's sister Maria of Austria stayed in the city of Naples for a few months. Apart from these visits of the royal family, which in Naples and Valencia were a rare exception and never took place in New Spain and the rest of Spanish America, the ruling dynasty was present through various events celebrated in the kingdoms' capitals. The funeral processions for a dead monarch and the proclamation of a new king were prime examples of such events as were the celebrations of births and weddings of members of the royal family.

From the local perspective, however, the most important ceremonies usually took place on the occasion of the solemn entries of the viceroys. Sometimes the death of a viceroy or that of his wife was the occasion for official, formally celebrated funeral ceremonies. In Naples the viceroy also opened and closed the corporative assemblies (parlamenti generali) of the kingdom,

29 Cf. the viceroy Duque de Alba who rearranged the chambers of the royal palace of Naples in 1622 using paintings representing his own family, Libro en que se trata de los Virreyes lugartenientes de estos reinos y de las cosas tocantes a su grandeza, compilado por José Raneo, año MDCXXXIV, é ilustrado con notas por D. Eustaquio Fernandez de Navarrete, parte I, Colección de documentos inéditos, vol. 23 (Madrid, 1853), 420-421, 427. 
occurrences which were repeated every few years. In addition, the viceroy was a pre-eminent guest at urban and church festivities on various occasions. Most of these festivities featured political ceremonies along with social events. ${ }^{30}$

Ceremonies taking place outside the royal palace, in which the viceroy as the king's representative participated, were usually organised by the town council or, on some occasions, by the chapter of the cathedral. Like the viceregal holding of court, these ceremonial events did not adhere to written regulations but relied on traditions of different urban, royal, or church ceremonies.

\section{Ceremonial Ranks and Conflicts at the Viceregal Court}

As an analysis of the various ceremonial practices shows, the political ceremonies held in the capitals of the kingdoms of Valencia, Naples, and New Spain were not one-sided representations of an 'absolute' monarchy; they reflected the ranks of individuals, groups, and institutions integrated within the complex political system of the Spanish monarchy. In the ceremony, the town council, which was recognised by royal writ as the political 'head' (cabeza) of the whole kingdom, faced the viceroy as an eminent institution in its own right. This standing became especially clear on the occasion of the viceregal entries, during which the viceroy in front of the political representatives of the capital of the kingdom was sworn in and vowed to honour and to defend the privileges of the kingdom. This ceremonial act held in the cathedral also symbolised the legitimacy of the monarchy through divine right. The viceroys were usually accompanied at these ceremonies by royal officials. The representatives of the nobility of the kingdoms, who assembled around the viceroys at these events, used these opportunities, in turn, to present themselves as loyal subjects of the monarchy.

Considering the complex political system of the Spanish monarchy and the fact that the viceroy as the highest political authority did not hold any sovereign rights, ceremonial interaction provided an especially appropriate space for competition and conflict of rank among the authorities of the king, the town, and the church. In addition, because the ceremonial rules and traditions observed at the viceregal courts and in the capitals of the kingdoms were not systematically regulated and fixed in writing, there was room for interpretation. At ceremonies organised by the town council or the church, viceroys

30 Regarding the public ceremonies in the viceregal capital of Valencia see María Pilar Monteagudo Robledo, 'El espectáculo del poder. Aproximación a la fiesta política en la Valencia de los siglos XVI-XVII', Estudis: Revista de historia moderna 19 (1993), 151-164. 
sometimes encountered unexpected innovations that often led to fierce conflicts, particularly when the information on possible precedents that could be used to solve the conflict, was too little, ambiguous, or contradictory. On the other hand, changes of the ceremonial order that were allegedly or actually against the law could easily become precedents for later rulings on similar conflicts of rank if the disadvantaged party was not able to protest successfully. For this reason, ceremonial acts regarding the viceregal court have to be interpreted not only as mere representations of the ranks and relations inherent in the political system of the Spanish monarchy but have to be understood also as a political procedure aimed at shaping the system they purport to represent. ${ }^{31}$

In the kingdoms investigated here, it was, in principle, the viceroys who as the highest political authorities made decisions on conflicts of rank concerning themselves or other groups and institutions. The viceroys, however, usually stayed in office for a few years only, arriving in the kingdom without specific knowledge about local norms and traditions. Therefore, they had to rely on the advice of local royal officials to judge in uncertain cases and appealed to the king in especially contentious cases.

Since the viceroy as royal governor exercised power delegated to him by the king and restricted in temporal and thematic scope, his possibilities to use ceremony for the manifestation and securing of his political authority were clearly limited. Thus, the viceroys, when carrying out ceremonial acts, had to rely not only on the king's approval but also on a consensus with the different social and political actors of the capital of the kingdom. This political consensus, however, could evaporate and thus needed to be re-established over and over again.

Some of these conflicts over rank arose in the framework of the viceregal holding of court and administration and concerned royal officials, nobles, and the personal entourage of the viceroy. For instance, in April 1621, Philip IV ordered the Neapolitan viceroy Cardinal Zapata to take back an order issued by some viceroys in the past, according to which the Spanish grandees had preference over the titled nobility and holders of the kingdom's honorary posts of the Sette Uffici at ceremonial acts in the royal palace. ${ }^{32}$ The cardinal was to

31 Cf. Barbara Stollberg-Rilinger, 'Zeremoniell, Ritual, Symbol. Neue Forschungen zur symbolischen Kommunikation in Spätmittelalter und Früher Neuzeit', Zeitschrift für historische Forschung 27, no. 3 (2000), 389-405.

32 The Norman king of Sicily and Naples, Roger II (1095-1154), originally had established the Sette Uffici as his royal council. The posts were traditionally reserved to the feudal aristocracy. During the reign of the Anjou (13th to $15^{\text {th }}$ centuries) these posts were reduced to honorary and ceremonial functions. 
return to the 'old custom' in effect since the times of the viceroy duke of Alcalá (1559-1571) and give both sides the same rank in order to prevent other 'new claims and difficulties' ('nuevas pretensiones y embaraços'). ${ }^{33}$ These orders from the king had been preceded by several letters of protest addressed to the king by the Neapolitan titular nobility and the Sette Uffici, who complained that since the issuing of an order during the time of the viceroy count of Lemos (1610-1616) the Spanish grandees had been assuming a preferred rank in the chapel and in the royal palace at the expense of the protesters. ${ }^{34}$ This conflict shows that, given the lack of systematic ceremonial regulations, order and ranking at the viceregal court left room for contradictory interpretations, out of which precedents for changes in the existing order could develop. The conflict shows also that even the king was not free to change or confirm ceremonial changes that disadvantaged one party or the other without running the risk of disturbing the social and political order.

Sometimes it was the contradiction between the rank by birth and the rank in the hierarchy of offices that caused conflicts as can be seen from an episode at the viceregal court of Naples. In November of 1621, the political representatives (eletti) of the town of Naples complained in a letter to Philip IV that the viceroy Cardinal Borja, governing as an interim appointee in 1620, had denied the eletti, who did not belong to the titular nobility, entry to the so-called 'chamber of the titled nobility'. Apparently, until that time, not only the eletti belonging to the titled nobility but also the other eletti waited in this room for the audiences granted to them by the viceroy to discuss general matters of town government. ${ }^{35}$ After the protests of the eletti against the changes he had introduced, the cardinal had referred to an order by Philip III. The eletti, in contrast, pointed out to Philip IV that it was appropriate to the dignity of the town that its eletti continue to enjoy this prerogative. The eletti represented the town and therefore the titled nobility, the Sette Uffici, and the Spanish grandees of the kingdom. Therefore, the eletti enjoyed pre-eminence over the kingdom's feudal aristocracy at the parliament general; for the same reason, the eletti had the right at meetings of the viceregal council (Consiglio Collaterale), in which they participated to discuss matters relevant for the town, of sitting down and covering their heads in the presence of the viceroy. Given their high political rank, the eletti asked the king, therefore, not to deny them entry to the

33 Letter of King Philip IV to Cardinal Zapata (Madrid, 15.4.1621), Archivo General de Simancas (AGS), Estado, leg. 1883, no. 390.

34 Consulta of the Council of Italy (Madrid, 29.5.1621), AGs, Secretaría de Nápoles, leg. 13.

35 Letter of Fabio Caracciolo to Philip IV (Madrid, 19.10.1621), AGs, Secretaría de Nápoles, book $623,102-102 \mathrm{v}$. 
chamber 'of the titled nobility'. Five years later, however, the king confirmed the decision made by his father in February of 1620 and implemented by Cardinal Borja to allow only members of the titular nobility entry to the chamber. ${ }^{36}$

In December 1631, at the request of the new Neapolitan viceroy count of Monterrey, the king ruled again on a conflict of rank between legal experts and noblemen, this time concerning the extended viceregal council (Consiglio di Stato e Guerra). ${ }^{37}$ The duke of Alcalá had reported to the king in a letter from February of that year that the councillors (consiglieri) belonging to the titled nobles claimed a principal preference over the legal experts (togati) belonging to the council, who did not have a title of nobility, independent of the seniority criterion. Because of this unsettled order of rank, many noble consiglieri stayed away from the meetings of the Consiglio and also from public occasions. The duke had, therefore, asked the king to let him know the criteria to be observed for the order of rank and seating arrangements. Philip IV then ruled that precedence and seating arrangements in the Consiglio were determined only by seniority and that any contestations had to be brought to the king, who alone was to decide about them. Thus, Philip IV reversed the previously prevailing order and gave priority to position over birth. In these two disputes, the decisions of Philip IV reflect a general tendency noticeable since the times of king Philip II (1556-1598): within the institutions of royal government, including the Consiglio di Stato e Guerra, the rank emanating from royal office prevailed increasingly over the privileges associated with social origin. ${ }^{38}$

One of the most frequent conflicts of rank fought out in ceremony involved the relationship of the viceroys to the archbishops and inquisitors, who, not least because of their position as representatives of the church and the pope, had a special sense of their political authority independent of the viceroys and who did not shy away from open conflicts with them. On the eve of a Mass said on April 15, 1621 in the cathedral of Valencia on the occasion of the Ascension of Christ, to which the chapter of the cathedral had invited, as usual, the viceroy marquis of Tavara (1619-1622), he learned that Archbishop Isidoro de

36 'Al Virrey de Nap.s. Renobando la orden que se dio p.a que no entren en la sala de los Titulados quien no lo es y reservando V. M.d asi solo el conceder esta gracia' (Madrid, 26.12.1625), AGS, Secretaría de Nápoles, book 435, 237v-238.

37 'Al conde de Monterey. Respuesta en materia de precedencia entre los del Consejo Collateral Togados y de capa y espada' (Naples, 12.12.1631), AGS, Secretaría de Nápoles, book 437, 267-267v.

38 José María García Marín, 'El dilema ciencia-experiencia en la selección del oficial público de la España de los Austrias', in José María García Marín, ed., Teoría política y gobierno en la monarquía hispánica (Madrid, 1998), 17-41. 
Aliaga had removed from the church the stone pulpit the archbishop usually used to give his sermons. Instead the archbishop had put up a podium decorated with carpets, tapestries, a canopy, various chairs, and an especially elaborate armchair (sitial). ${ }^{39}$ The marquis asked the archbishop then to refrain from this novelty ('novedad'). To avoid a conflict he suggested to Aliaga to let the king decide this matter. The archbishop, however, rejected this suggestion, and the marquis, after talking to the royal master of ceremonies (maestre de ceremonias), insisted on his position.

The next morning, the viceroy tried again to get the archbishop to reconsider. The archbishop, however, called various armed theology students and lower-ranking clerics to Mass to defend him against possible action by the viceroy. After this, the marquis consulted with various royal officials, who all agreed that the viceroy was right. On the officials' advice, the viceroy abandoned his previous decision of confronting the archbishop personally in the church. To prevent an escalation of the conflict, the viceroy finally decided to stay away from Mass. On the following day, he informed the king about the incident in writing and asked for a ruling. He pointed out to Philip IV that in 1615 Aliaga had been reprimanded by the viceroy of that time, marquis of Caracena (1606-1615), for similar behaviour. In addition, a minion of the archbishop was taken into custody by order of the local royal court of justice on the same day. On the previous day this individual had, together with students armed with pistols, made sure that the sitial put up by the archbishop was not removed from the church. ${ }^{40}$

The archbishop justified his claim to the right to sit under a canopy and on a sitial even in the presence of the viceroy in a letter sent to the king through the marquis by saying that this practice agreed with the Roman ceremonial and with the traditional practice of the Roman Church. ${ }^{41}$ The viceroy and his advisors, however, insisted that all of the former Valencian archbishops at the Masses said by them had needed only a simple chair ('silla movil') put on a carpet and a cushion lying in front of it, which, in turn, agreed with the Roman ceremonial. ${ }^{42} \mathrm{~A}$ change of this old tradition would create a note of discord.

39 Letter of the marquis of Tavara to Philip IV (Valencia, 25.4.1621), Archivo de la Corona de Aragón, Consejo de Aragón (ACA/CA), Secretaría de Valencia, leg. 682, doc. 58/1-2. Coses evengudes en la ciutat y regne de Valencia. Dietario de mosen Juan Porcar, capellán de San Martín (1589-1629) (Madrid, 1934), vol. 1, 46.

41 Letter of Archbishop Isidoro de Aliaga to Philip IV (Valencia, undated), ACA/CA, Secretaría de Valencia, leg. 682, doc. 57/6-9.

42 'Racones por donde no pertenece al Arcobispo de Valencia predicar en la forma que pretende' (Valencia, undated), ACA/CA, Secretaría de Valencia, leg. 682, doc. 57/23-24. 
In the town of Valencia it was an 'established fact' ('cosa asentada') that in the presence of the royal governor during public occasions the archbishop was entitled only to a simple chair and a cushion. The archbishop was not even allowed to put up a sitial in the presence of the members of the town council (jurats). Such a prohibition holds all the more true for the viceroy. If the jurats met with the viceroy who was seated on a sitial, they, in turn, would be allowed to sit down only on the pews. The archbishop's present claim, the viceroy argued, was based on his imagination alone and contradicted both the Roman ceremonial and the practice in Valencia.

After an extensive investigation of the matter lasting more than a year, the king agreed with the viceroy's protest and gave the archbishop two alternatives for future Masses, practiced by his predecessors, to choose from: he was to hold his sermon either from a simple chair without a canopy on a small podium or from the normal pulpit decorated with a silk cloth. ${ }^{43}$ At the same time, the bishop of Teruel was, at Philip's IV request, put in charge of a papal commission to start investigating those clerics who had been present at the Mass on April 15, $1621 .{ }^{44}$

This conflict was only one of the matters of dispute between the viceroy and the archbishop. In the year since he had taken up his office the marquis of Tavara had been engaged in various conflicts of jurisdiction with Aliaga, especially with regard to the prosecution of clerics accused of possessing illegal weapons. ${ }^{45}$ Since the ecclesiastical court of Valencia refused to initiate legal proceedings against the clerics, the royal court (Audiencia) ordered their arrest in June 1620. As a consequence, the vicar-general of the ecclesiastical court declared the excommunication of the royal officials who had carried out the arrest. Since Aliaga rejected the viceroy's demand to intervene in the dispute, the marquis and the judges of the Audiencia, following an order of King Philip III, initiated legal proceedings against the properties of the archbishop, who answered with a declaration of an interdict.

Although the dispute was settled a few days later and was followed in 1622 by an ecclesiastical visitation ordered by Philip IV and approved by Pope

43 'Al Virrey de Val.a con aviso de la resolucion q.e tiene tomada V. M.d respecto de la forma en que ha de predicar el Arçobispo de aquella ygla. Consultado' (Madrid, 23.6.1622), Archivo Histórico Nacional (AHN), Madrid, Consejo de Aragón, book 2409, 108v-109.

44 Consulta of the Council of Aragon (Madrid, 2.11.1625), ACA/CA, Secretaría de Valencia, leg. 650, doc. 5/1-3.

45 Letter of the marquis of Tavara to Philip III (Valencia, 2.8.1620), ACA/CA, Secretaría de Valencia, leg. 682, doc. 94/1-2. 
Gregory $\mathrm{XV},{ }^{46}$ political conflicts between Aliaga and the viceroy continued during the period of office of viceroy Tavara's successor, the marquis of Pobar $(1622-1627) \cdot{ }^{47}$ Again, ceremonial disputes accompanied jurisdictional conflicts, as the viceroy and the archbishop were central elements of political communication and interaction within the political system of the Spanish monarchy.

The role of ceremonial acts and jurisdictional affairs as opportunities and means of political competition among various political authorities at the viceregal court and in the capital of the kingdom become even more conspicuous in the case of the New-Spanish viceroy marquis of Gelves (1621-1624). In 1623, Philip IV ruled on a conflict between the marquis and the royal judges (oidores) acting as members of the viceregal council (Real Acuerdo), who at public events in the cathedral decorated their knee benches with cushions, which was, according to the existing regulations, a right of the viceroy alone. In response to a query by Philip IV, the marquis pointed out that this abuse had been practiced already during the term of the viceroy marquis of Guadalcázar (1612-1621). In August 1623, the king ordered the oidores to stop using cushions immediately. Existing regulations specified that the presiding senior oidor was entitled to a chair covered with velvet and a cushioned knee bench only if the position of the viceroy was vacant. ${ }^{48}$ Thus, the king confirmed the ceremonial priority of the viceroy over the other royal officials, with whom the marquis had disputed questions of jurisdiction for quite some time as had his predecessor.

The special position of the viceroy as the monarch's alter ego and as the head of the capital of the kingdom also led to various conflicts at ceremonial events. In 1622 the marquis of Gelves (1621-1624), who made special efforts to maintain his authority in office, even banished two councillors (regidores) from town after they had refused to escort him together with the other members of the town council from the royal palace to the cathedral on the occasion of a Mass for the Día de la Candelaria. ${ }^{49}$ The town council (Cabildo) informed

46 Papal brief of Gregory XV (copy, Madrid, 20.9.1622), ACA/CA, Secretaría de Valencia, leg. 682, doc. 67 .

47 Letter of Archbishop Isidoro de Aliaga to Philip IV (Valencia, 5·7.1622), ACA/CA, Secretaría de Valencia, leg. 707, doc. 83/1-3.

48 'A la Aud.a de Mex.co dandole la forma en q.e a de tener los asientos en los actos publicos y en los que no lo fuesen' (Madrid, 12.8.1623), AG I, Audiencia de México, leg. 1065, book 7 , $84 \mathrm{v}-85$.

49 'Cargos del marq.s de Gelves en 46 fol.s' (Mexico, 23.10.1626), in: 'Proceso imcompleto de la Visita hecha en Megico por D.n Martin Carrillo Alderete: año 1627', AGI, Audiencia de México, leg. 329 . 
the king about this incident and insisted that the regidores were not obliged to accompany the viceroy to the cathedral. Moreover, the town had been represented in the cathedral by several regidores. No final ruling by the king about this incident can be found in the documentation. However, Philip IV ordered the marquis in March 1623 to let the regidores, who had been banished because of this incident, return to town immediately and to let them take up their offices awaiting further decisions on the case. ${ }^{50}$

During his period of office the marquis of Gelves engaged in conflicts over rank and jurisdiction with almost all the urban, royal, and clerical institutions. ${ }^{51}$ Although the marquis has long been identified in historiography as an outstanding protagonist of the 'absolutist' politics of reform of Philip IV and his favourite, the count-duke of Olivares, ${ }^{52}$ the documentation of the various political conflicts the viceroy was engaged in, which reached their climax in the declaration of an interdict and the excommunication of the viceroy by Archbishop Juan Pérez de la Serna followed by an attack on the royal palace by the populace in January 1624, tells another story. The sources on ceremony and jurisdiction show the marquis, an experienced servant of the king, as a distinguished member of the titled nobility of Castile, resolutely defending his rank against persistent challenges by various local political actors.

The Marquis and the Archbishop were both finally relieved from office by the king in 1624. Gelves' successor, the marquis of Cerralvo (1625-1635), tried to prevent ceremonial and jurisdictional confrontations with Pérez de la Serna's successor, Francisco de Manso y Zúñiga, by being more open to compromises or by not attending ceremonial occasions in the cathedral. Nonetheless, conflicts of ceremony and jurisdiction between viceroy and archbishop went on for several more years until both were relieved from office in 1635 .

\section{Final Remarks}

The conflicts of rank between the individuals, groups, and institutions all integrated within the political system of the Spanish monarchy make clear that

50 'Al Virrey de nueva esp.a que en el entretanto que se determina en el conss.o la caussa que le a remetido de ocho regidores de la ciu.d de Mex.co los haga bolber a ella alçandoles la carceleria sin fianzas' (Madrid, 20.3.1623), AGI, Audiencia de México, leg. 1065, book 7, $54 \mathrm{v}-55 \mathrm{v}$.

51 Büschges, ‘¿Absolutismo virreinal?’, 36-40.

52 Richard Boyer, 'Absolutism versus corporatism in New Spain. The administration of the marquis of Gelves, 1621-1624', International History Review 4, no. 4 (1982), 475-503. 
ceremonial acts were seen by all participants as important elements of political communication and interaction. Therefore, the ceremonies at the viceregal court are not only to be interpreted as symbolic representations of a system of rule that concentrated on the monarch but have to be considered as part of the execution and shaping of this multifaceted system. The viceroy and the other actors around the viceregal court, without denying the king's sovereignty, sought to manifest, defend, and enhance their positions within the political system. In this context, ceremony and its attendant conflicts not only made manifest the tensions in the multi-layered political elite, but also defined and recreated the relationships among the political actors. The disputes over ceremony and jurisdiction that the Spanish viceroys had with other royal, ecclesiastical or municipal authorities did not differ in substance from the situation at European royal courts. Nonetheless, the absence of the king and the limited power of the viceroy made these conflicts sometimes especially severe and long lasting, particularly in the remote areas of Spanish America.

However, the distance of the Spanish American realms from the Iberian Peninsula and the royal court at Madrid cannot be taken as a general indicator for differentiating the European viceregal courts from their American counterparts. On the one hand, personal skills of particular viceroys were always a decisive element in dealing with the social and political tensions inherent within the composite monarchy of the Spanish Habsburgs on both sides of the Atlantic. On the other hand, differences with regard to institutional settings, political traditions, and social relations existed also within the European context and had a decisive impact on ceremonial practice and dispute. 